OSEANOLOGI DAN LIMNOLOGI DI INDONESIA

Online ISSN: 2477-328X

Akreditasi RISTEKDIKTI No. 200/M/KPT/2020

http://oldi.lipi.go.id

\title{
Pengaruh Padat Tebar terhadap Konsumsi Oksigen dan Respons Stres Ikan Cupang Alam (Betta imbellis)
}

\author{
Shofihar Sinansari ${ }^{1}$, Vitas Atmadi Prakoso ${ }^{2}$, Erma Primanita Hayuningtyas ${ }^{1}$, \\ Bambang Priadi ${ }^{2}$, Sri Sundari ${ }^{2}$, Eni Kusrini ${ }^{1}$ \\ ${ }^{1}$ Balai Riset Budidaya Ikan Hias, Depok, Jl. Perikanan Raya No.13, Pancoran Mas, \\ Kota Depok, Jawa Barat 16436 \\ ${ }^{2}$ Balai Riset Perikanan Budidaya Air Tawar dan Penyuluhan Perikanan, Bogor, \\ Jl. Sempur No. 1, Bogor, Jawa Barat 16129 \\ Email: vitas.atmadi@gmail.com
}

Submitted 23 April 2020. Reviewed 3 August 2020. Accepted 25 August 2020.

DOI: 10.14203/oldi.2021.v6i1.314

\begin{abstract}
Abstrak
Padat tebar merupakan salah satu parameter penentu untuk mengoptimalkan pertumbuhan ikan dalam sistem budidaya karena berhubungan dengan metabolisme ikan. Informasi mengenai pengaruh perbedaan padat tebar terhadap metabolisme belum tersedia pada ikan cupang alam (Betta imbellis). Penelitian ini bertujuan untuk menganalisis pengaruh padat tebar terhadap konsumsi oksigen, kadar oksigen terlarut kritis, dan respons stres pada ikan cupang alam. Penelitian dilakukan dengan tiga perlakuan padat tebar yang berbeda yaitu 5, 10, dan 15 ekor/L, dan masing-masing dilakukan dalam tiga ulangan menggunakan ikan uji dengan panjang total $2,74 \pm 0,23 \mathrm{~cm}$ dan bobot $0,22 \pm 0,05 \mathrm{~g}$. Parameter yang diamati yaitu konsumsi oksigen, laju ventilasi, kadar glukosa darah, kortisol, dan kadar oksigen kritis. Hasil penelitian menunjukkan bahwa konsumsi oksigen tertinggi ditemukan pada perlakuan padat tebar 5 ekor/L $(3,01 \pm 0,28 \mathrm{mg} \mathrm{O} / \mathrm{g} / \mathrm{jam})$. Hal ini berbeda nyata dengan perlakuan 10 ekor/L $(1,01 \pm 0,21 \mathrm{mg} \mathrm{O} / \mathrm{g} / \mathrm{jam})$ dan $15 \mathrm{ekor} / \mathrm{L}(0,92 \pm 0,08 \mathrm{mg}$ $\mathrm{O}_{2} / \mathrm{g} / \mathrm{jam}$ ). Konsumsi oksigen tidak berbeda nyata saat hipoksia maupun normoksia, sedangkan laju ventilasi cenderung mengalami kenaikan yang berbeda nyata dengan peningkatan padat tebar pada kedua kondisi tersebut. Kadar oksigen kritis tidak berbeda nyata antar perlakuan, yaitu 3,31 $\pm 0,65 \mathrm{mg} / \mathrm{L}, 3,14 \pm 0,29 \mathrm{mg} / \mathrm{L}$, dan 2,83 $\pm 0,19 \mathrm{mg} / \mathrm{L}$ masing-masing untuk padat tebar 5, 10, dan 15 ekor/L. Kadar glukosa darah secara berbeda nyata lebih tinggi pada perlakuan padat tebar 15 ekor/L dibandingkan perlakuan yang lain, sedangkan kadar kortisol tidak berbeda antara perlakuan. Hasil penelitian ini memberikan informasi bahwa ikan cupang alam merespon peningkatan padat tebar dengan penurunan aktivitas metabolisme dan peningkatan laju ventilasi. Namun, peningkatan laju ventilasi berkorelasi negatif terhadap konsumsi oksigen dalam sekali bernapas pada padat tebar yang lebih tinggi akibat adanya penurunan aktivitas ikan, sehingga terjadi penurunan konsumsi oksigen pada kondisi padat tebar yang lebih tinggi. Berdasarkan hasil pengukuran konsumsi oksigen dan parameter respons stres dalam penelitian ini, dapat disimpulkan bahwa padat tebar ideal bagi ikan cupang alam adalah 5 ekor/L. Peningkatan padat tebar menyebabkan penurunan tingkat konsumsi oksigen dan peningkatan stres bagi spesies ikan ini.
\end{abstract}

Kata kunci: Betta imbellis, padat tebar, konsumsi oksigen, stres.

\section{Abstract}

Effect of Stocking Density on Oxygen Consumption and Stress Response in Crescent Betta (Betta imbellis). Stocking density is one of the determinant parameters for fish growth optimization in 
aquaculture systems due to its relationship with fish metabolism. Information about the impact of different stocking densities on crescent betta (Betta imbellis) metabolism was not available yet. This study was aimed to analyze the effect of stocking density on oxygen consumption, critical oxygen level, and stress responses in crescent betta.The study was carried out under three different stocking density treatments: 5, 10, and 15 fish/L with three replications using $2.74 \pm 0.23 \mathrm{~cm}$ total length and $0.22 \pm 0.05 \mathrm{~g}$ body weight tested fishes.The parameters observed were oxygen consumption, ventilation rate, blood glucose level, cortisol, and critical oxygen level. The result showed that the highest oxygen consumption was found at $5 \mathrm{fish} / \mathrm{L}$ stocking density treatment $(3.01 \pm 0.28 \mathrm{mg} \mathrm{O} / \mathrm{g} / \mathrm{h})$, which was significantly different from $10 \mathrm{fish} / \mathrm{L}(1.01 \pm 0.21 \mathrm{mg}$ $\left.\mathrm{O}_{2} / \mathrm{g} / \mathrm{h}\right)$ and $15 \mathrm{fish} / \mathrm{L}\left(0.92 \pm 0.08 \mathrm{mg} \mathrm{O}_{2} / \mathrm{g} / \mathrm{h}\right)$ stocking density treatments. Oxygen consumptions under hypoxic condition was not significantly different compared to normoxic condition. The ventilation rate tends to increase significantly along with the increasing of stocking densities. Critical oxygen levels were not significantly different among the treatments, with the value of $3.31 \pm 0.65 \mathrm{mg} / \mathrm{L}, 3.14 \pm 0.29 \mathrm{mg} / \mathrm{L}$, and 2.83 $\pm 0.19 \mathrm{mg} / \mathrm{L}$ for stocking density of 5,10 , and $15 \mathrm{fish} / \mathrm{L}$, respectively. The blood glucose level at $15 \mathrm{fish} / \mathrm{L}$ stocking density was significantly higher than others, whereas the cortisol levels was not significantly different among the treatments. The results of this study provided information that the increasing stocking density of cressent betta will decrease their metabolism activity and increase ventilation rate. However, the increase of ventilation rate was negatively correlated with oxygen consumption per breath at higher stocking densities due to decrease in fish activity; and higher stocking densities will decrease oxygen consumption. Based on the results, it can be concluded that the ideal stocking density for crescent betta is 5 fish/L. The increasing of stocking density will decrease oxygen consumption rates and increase the stress level of crescent betta.

Keywords: Betta imbellis, stocking density, oxygen consumption, stress.

\section{Pendahuluan}

Ikan cupang alam (Betta imbellis) memiliki tubuh berwarna-warni, bentuk sirip yang indah, harga yang tinggi, dan sangat diminati oleh para pecinta ikan hias, sehingga ikan ini perlu diteliti dan didomestikasi untuk keperluan konservasi dan budidaya. Balai Riset Budidaya Ikan Hias (BRBIH) telah berhasil membudidayakan ikan cupang alam asal Sumatera sebagai hasil domestikasi. Ikan ini tergolong unik karena memiliki labirin dan insang sebagai alat pernapasan (Hui \& Ng, 2005). Ikan cupang mampu memperoleh oksigen baik dari air maupun dari udara, sehingga ikan ini tidak membutuhkan air dengan kandungan oksigen yang tinggi untuk bertahan hidup. Oleh karena itu, budidaya ikan ini sangat mudah karena tidak membutuhkan peralatan untuk meningkatkan kadar oksigen terlarut pada media pemeliharaannya. Beberapa penelitian pada ikan cupang alam ini juga sudah dilakukan, di antaranya yaitu terkait pemijahan dan pemeliharaan larva (Murniasih et al., 2012), perkembangan embrio (Cindelaras et al., 2015), pertumbuhan larva pada suhu pemeliharaan yang berbeda (Rahmawati \& Kusrini, 2016), performa pertumbuhan dengan pemberian hormon (Hayuningtyas \& Kusrini, 2016), transfer gen (Prasetio et al., 2013; Kusrini et al., 2016), dan performa hasil transgeniknya (Kusrini et al., 2018).
Beberapa parameter kualitas air memiliki pengaruh yang penting dalam proses budidaya ikan, seperti suhu, $\mathrm{pH}$, oksigen terlarut, alkalinitas, amonia, dan nitrit. Khususnya pada parameter oksigen terlarut, oksigen berperan dalam proses metabolisme ikan untuk menghasilkan energi. Menurut Faturrohman (2017), oksigen berperan dalam membantu proses metabolisme sehingga menghasilkan energi yang selanjutnya digunakan dalam proses pertumbuhan. Penurunan kandungan oksigen di bawah titik minimum kebutuhan oksigen pada ikan diduga dapat menyebabkan stres, bahkan dapat menyebabkan kematian ikan (Tripathi et al., 2013; Ni et al., 2014; Prakoso et al., 2019a). Secara umum, respons stres berkorelasi dengan ciri tingkah laku, sehingga membentuk pola yang digambarkan sebagai cara mengatasi stres (Koolhaas et al., 1999). Ikan akan merespons stresor dengan cara yang berbeda-beda dalam pola tingkah lakunya, umumnya dicirikan oleh tingkat agresi, neophobia, aktivitas lokomotor umum, serta kecenderungan untuk mengubah rutinitas tingkah laku (Overli et al., 2007). Jika dapat mengatasi stres, maka ikan akan pulih ke homeostatis normal yang serupa atau yang agak mirip. Konsekuensi jangka panjang dari paparan stresor yang berulang atau berkepanjangan adalah kondisi maladaptive yang secara negatif memengaruhi fungsi-fungsi kehidupan ikan yang diperlukan (pertumbuhan, perkembangan, resistensi penyakit, perilaku, dan reproduksi). Hal 
tersebut sebagian besar berhubungan dengan energi yang diperlukan untuk menjaga respons stres (Schreck \& Tort, 2016). Kadar kortisol dan glukosa darah merupakan dua parameter yang dapat menggambarkan keadaan respons fisiologis ikan atas lingkungan yang tidak mendukung (Wedemeyer et al., 1990; Morgan \& Iwama, 2011). Menurut Watkins (2008), kebutuhan energi untuk memperbaiki homeostasis selama stres dipenuhi oleh proses glikogenolisis dan glukoneogenesis yang menghasilkan glukosa. Selain glukosa, parameter lain yang umumnya digunakan untuk mengukur stres pada ikan adalah kortisol (Sadoul \& Geffroy, 2019). Kortisol merupakan salah satu hormon yang menginisiasi respon stres dan kadarnya akan meningkat apabila ikan mengalami stres (Lays et al., 2009; Cook \& Herbert, 2012; Ni et al., 2014; Schreck \& Tort, 2016) sehingga parameter ini dapat dijadikan sebagai indikator stres pada ikan.

Tingkat keberhasilan usaha budidaya sering dipengaruhi oleh kemampuan mengatasi masalah kandungan oksigen terlarut (Boyd, 1982). Arifin et al. (2017a) melaporkan bahwa oksigen terlarut di bawah $3 \mathrm{mg} / \mathrm{L}$ menyebabkan aktivitas ikan tambakan (Helostoma temminckii) terganggu dan pada akhirnya menyebabkan kematian seluruh ikan apabila tingkat oksigen terlarut terus mengalami penurunan. Prakoso et al. (2019a) juga mengemukakan bahwa kadar oksigen kritis untuk benih ikan baung (Hemibagrus nemurus) adalah $1,81 \pm 0,54 \mathrm{mg} / \mathrm{L}$. Tingkat penurunan konsumsi oksigen dapat dikaitkan dengan penurunan aktivitas dan peningkatan stres pada kondisi hipoksia dibandingkan dengan kondisi normoksia (Domenici et al., 2013; Prakoso et al., 2016). Secara definisi, normoksia merupakan tingkat oksigen yang diperlukan untuk proses fisiologis normal terjadi, yang juga merupakan tingkat optimal untuk oksigen dalam tubuh. Sementara itu, hipoksia didefinisikan sebagai kekurangan oksigen dalam tubuh yang dihasilkan karena perbedaan antara pasokan oksigen dan konsumsi oksigen (Kulkarni et al., 2007). Wahyu et al. (2015) juga berpendapat bahwa stres yang dialami ikan akan menimbulkan perubahan respons fisiologis seperti perubahan hematologi dan $\mathrm{pH}$ darah.

Selain oksigen sebagai faktor pembatas dalam budidaya ikan, padat tebar yang tidak sesuai dalam pemeliharaan ikan dapat mengakibatkan persaingan dalam media pemeliharaan, stres pada ikan hingga berujung pada kematian. Hasil penelitian mengenai padat tebar optimal pada benih ikan lalawak dengan bobot awal 14,89 $\pm 0,13$ g dilaporkan sebesar 10 ekor $/ \mathrm{m}^{3}$ (Arifin et al., 2017b), larva ikan botia dengan panjang awal $5 \mathrm{~mm}$ pada padat tebar 15 ekor/L (Priyadi et al., 2010), dan benih ikan silver dollar dengan panjang awal 2,13 $\pm 0,02 \mathrm{~cm}$ padat tebar 1 ekor/L (Kadarini et al., 2010). Hepher \& Pruginin (1981) mengemukakan bahwa peningkatan padat tebar ikan menurunkan kandungan oksigen terlarut akibat peningkatan kebutuhan oksigen untuk respirasi.

Studi mengenai pengaruh padat tebar terhadap metabolisme, konsumsi oksigen, dan laju ventilasi pada beberapa penelitian terdahulu telah dilakukan pada beberapa spesies ikan, seperti ikan belanak (Chelon labrosus) (De las Heras et al., 2015), ikan meagre (Argyrosomus regius) (Millan-Cubillo, 2016), ikan amur sturgeon (Acipenser schrenckii) (Ren et al., 2017), dan ikan uceng (Nemacheilus fasciatus) (Iswantari et al., 2019). Namun, informasi mengenai konsumsi oksigen, laju ventilasi, kadar oksigen kritis, dan padat tebar optimal bagi ikan cupang alam masih belum banyak dilaporkan. Selain itu, padat tebar dan konsumsi oksigen ini juga merupakan parameter penting dari serangkaian persyaratan rilis komoditas ikan baru di Indonesia. Kementerian Kelautan dan Perikanan telah mengatur rilis komoditas ikan baru melalui kegiatan domestikasi yang harus mengacu pada Permen KP No. 84/Permen-KP/2014; Perka Balitbang KP No. 84 dan 85/Per-Balitbang$\mathrm{KP} / 2014$. Tujuan penelitian ini yaitu untuk mengetahui konsumsi oksigen, kadar oksigen terlarut kritis, dan respon stres ikan cupang alam pada padat tebar berbeda.

\section{Metodologi}

Penelitian ini dilakukan di Balai Riset Perikanan Budidaya Air Tawar dan Penyuluhan Perikanan (BRPBATPP) Bogor pada bulan Agustus-September 2019. Padat tebar yang digunakan dalam penelitian ini yaitu 7, 14, dan 21 ekor per wadah respirometer atau setara dengan 5 , 10, dan 15 ekor/L (mengacu pada metode yang dilakukan oleh Iswantari et al., (2019). Padat tebar yang digunakan dalam penelitian ini ditentukan berdasarkan penelitian pendahuluan yang menunjukkan adanya perbedaan pertumbuhan pada ketiga perlakuan padat tebar tersebut. Ikan uji dengan panjang total $2,74 \pm 0,23 \mathrm{~cm}$ dan bobot $0,22 \pm 0,05 \mathrm{~g}$ dipelihara selama 14 hari di akuarium laboratorium basah sebelum percobaan. Selama pemeliharaan, ikan diberi pakan cacing darah beku (protein $60-62,5 \%$ dan lemak 10\%) sebanyak 3\% dari biomassa ikan tersebut per hari. Pakan diberikan pada pagi dan sore hari. Sehari sebelum percobaan, ikan dipuasakan untuk menghindari pengaruh pakan terhadap 
metabolisme. Selama percobaan pengukuran konsumsi oksigen, ikan juga dipuasakan. Hal ini mengacu pada metode penelitian yang dilakukan oleh Chang et al. (2005) dan Jeong et al. (2007).

Pengukuran konsumsi oksigen dilakukan setelah 24 jam ikan dipuasakan. Pengukuran dilakukan menggunakan respirometer tertutup bervolume 1,4 L. Alat pengukur dan sensor oksigen (Trans Instrument HD3030, Singapore) dihubungkan pada respirometer untuk mengukur konsentrasi oksigen terlarut. Percobaan dilakukan pada tiga perlakuan padat tebar dengan masingmasing perlakuan dilakukan sebanyak tiga ulangan. Pengukuran dilakukan pada awal percobaan. Selama pengukuran, suhu air dan $\mathrm{pH}$ pada respirometer dijaga konstan pada 27,5 $\pm 0,7$ dan $7,6 \pm 0,6$. Pengukuran konsentrasi oksigen terlarut dilakukan setiap 10 menit sampai pengamatan selesai (1-2 jam). Tingkah laku ikan cupang alam berupa aktivitas ikan saat di dalam respirometer diamati selama pengukuran konsentrasi oksigen terlarut. Laju ventilasi atau frekuensi bernapas diukur menggunakan metode Wares \& Igram (1979). Konsumsi oksigen dihitung dengan rumus Kawamoto (1977) sebagai berikut:

Keterangan:

$$
O C=\left(\mathrm{DO}_{0}-\mathrm{DO}_{\mathrm{t}}\right) \times \frac{\mathrm{V}}{\mathrm{t} \times \mathrm{W}}
$$

$$
\begin{aligned}
\mathrm{OC}= & \text { konsumsi oksigen yang dinyatakan } \\
& \text { dalam miligram oksigen per jam per } \\
& \text { gram ikan } \\
\mathrm{DO}_{0}= & \text { oksigen terlarut awal }\left(\mathrm{mg} \mathrm{O}_{2} / \mathrm{L}\right) \\
\mathrm{DO}_{\mathrm{t}}= & \text { oksigen terlarut setelah } \mathrm{t} \text { jam }(\mathrm{mg} \\
& \left.\mathrm{O}_{2} / \mathrm{L}\right) \\
\mathrm{t}= & \text { lama waktu pengukuran }(\mathrm{jam}) \\
\mathrm{V}= & \text { volume air dalam respirometer }(\mathrm{L}) \\
\mathrm{W}= & \text { bobot ikan }(\mathrm{g})
\end{aligned}
$$

Selain konsumsi oksigen, kadar oksigen kritis juga diukur dalam penelitian ini dengan mengacu pada Schurmann \& Steffensen (1997). Kadar oksigen kritis adalah nilai oksigen terlarut saat konsumsi oksigen/laju metabolisme ikan lebih rendah dibandingkan laju metabolisme standar (standard metabolic rate) saat terjadi penurunan dari tingkat jenuh ke tingkat hipoksia (Portner et al. 1985). Laju metabolisme standar merupakan energi minimum yang dibutuhkan ikan untuk bertahan hidup, terkait dengan kondisi saat istirahat dan tidak diberi pakan (Brett, 1964). Pada penelitian ini, sebelum penentuan kadar oksigen kritis, laju metabolisme standar diukur dengan mengukur konsumsi oksigen dalam masingmasing ulangan dan perlakuan saat kondisi normoksia menggunakan metode dan kalkukasi yang sama dengan pengukuran konsumsi oksigen 14
(Kawamoto, 1977). Kemudian, ikan dari setiap perlakuan dan ulangan diukur konsumsi oksigennya sampai pada saat kondisi hipoksia. Kadar oksigen terlarut dalam kondisi hipoksia yang nilai konsumsi oksigennya tercatat lebih rendah daripada laju metabolisme standar inilah yang ditentukan sebagai kadar oksigen kritis.

Sebagai data pendukung, kadar glukosa darah dan kortisol juga dihitung dari masingmasing perlakuan serta kontrol pada akhir penelitian, yaitu ikan yang dipelihara di akuarium dengan kepadatan 5 ekor/L tanpa pernah dimasukkan ke dalam respirometer. Ikan di akuarium tersebut diambil sampel darahnya sebagai pembanding dengan ikan-ikan yang dimasukkan ke dalam respirometer dan digunakan dalam perlakuan $(\mathrm{n}=3$ ekor). Jumlah darah yang diambil dan metode pengambilan sampel darah untuk analisis glukosa dan kortisol mengacu pada Prakoso et al. (2019b).

Data konsentrasi oksigen terlarut untuk menentukan tingkat konsumsi oksigen dikelompokkan menjadi dua, yaitu kondisi normoksia pada saat nilai oksigen terlarut di atas 5 $\mathrm{mg} / \mathrm{L}$ dan saat kondisi hipoksia pada saat nilai oksigen terlarut lebih rendah dari $5 \mathrm{mg} / \mathrm{L}$ (Pichavant et al., 2000; Pichavant et al., 2001). Selanjutnya, data konsumsi oksigen, glukosa darah, dan kortisol yang diperoleh dari hasil penelitian dianalisis dengan analisis stastistik ANOVA satu arah dengan nilai tingkat kepercayaan $5 \% \quad(p<0,05)$, sedangkan data konsumsi oksigen pada kondisi normoksia dan hipoksiadianalisis dengan analisis statistik uji-t dengan nilai tingkat kepercayaan $1 \%(p<0,01)$. Semua uji tersebut dilakukan dengan menggunakan perangkat lunak statistik PASW Statistics 18.

\section{Hasil}

Hasil pengukuran konsumsi oksigen pada ikan cupang alam pada padat tebar yang berbeda diperlihatkan dalam Tabel 1. Hasil pengamatan menunjukkan bahwa konsumsi oksigen cenderung menurun dengan peningkatan padat tebar. Nilai pada kondisi normoksia lebih tinggi dan berbeda nyata pada perlakuan padat tebar 5 ekor/L dibandingkan dengan perlakuan yang lain $(p<0,05)$. Sementara itu, konsumsi oksigen pada perlakuan padat tebar 10 dan 15 ekor/L saat normoksia tidak berbeda nyata $(p>0,05)$. Sama halnya dengan kondisi normoksia, konsumsi oksigen juga lebih tinggi dan berbeda nyata pada perlakuan padat tebar 5 ekor/L dibandingkan dengan perlakuan 10 dan 15 ekor/L $(p<0,05)$. Konsumsi oksigen pada perlakuan padat tebar 10 
dan 15 ekor/L saat hipoksia juga tidak berbeda nyata $(p>0,05)$. Akan tetapi, konsumsi oksigen saat hipoksia pada perlakuan padat tebar 5 ekor/L memiliki variasi yang tinggi antarulangan jika dibandingkan dengan perlakuan padat tebar 10 dan 15 ekor/L. Secara keseluruhan, konsumsi oksigen saat normoksia dan hipoksia tidak berbeda nyata pada perlakuan padat tebar5 ekor/L $(p>0,01)$. Sedangkan konsumsi oksigen saat normoksia secara berbeda nyata lebih tinggi dibandingkan saat hipoksia pada perlakuan padat tebar 10 dan 15 ekor/L $\quad(p<0,01)$.

Tabel 1. Konsumsi oksigen ikan cupang alam (Betta imbellis) pada padat tebar yang berbeda dalam kondisi normoksia dan hipoksia.

Table 1. Oxygen consumption of crescent betta (Betta imbellis) under different stocking densities during normoxia and hypoxia.

\begin{tabular}{ccc}
\hline \multirow{2}{*}{ Stocking density $(\mathrm{fish} / \mathrm{L})$} & \multicolumn{2}{c}{ Oxygen consumption $\left(\mathrm{mg} \mathrm{O}_{2} / \mathrm{g} / \mathrm{h}\right)$} \\
\cline { 2 - 3 } & Normoxia & Hypoxia \\
\hline 5 & $3.01 \pm 0.28^{\mathrm{b}^{*}}$ & $2.81 \pm 1.84^{\mathrm{y}^{*}}$ \\
10 & $1.01 \pm 0.21^{\mathrm{a}^{* *}}$ & $0.40 \pm 0.10^{\mathrm{x}^{*}}$ \\
15 & $0.92 \pm 0.08^{\mathrm{a}^{* *}}$ & $0.53 \pm 0.20^{\mathrm{x}^{*}}$ \\
\hline
\end{tabular}

Keterangan: Nilai merupakan rata-rata \pm SD $(n=3)$. Superskrip alfabet yang berbeda menunjukkan nilai berbeda nyata antara padat tebar yang berbeda $(p<0,05$, ANOVA satu arah). Superskrip bintang menunjukkan nilai berbeda nyata antara kondisi normoksia dan hipoksia $(p<0,01$, uji-t).

Description: Mean values \pm SD $(n=3)$. Different alphabet superscripts show significant differences between different stocking densities ( $p<0.05$, one-way ANOVA). Asterisk superscripts show significant differences between normoxia and hypoxia $(p<0,01$, t-test).

Secara umum, hasil observasi menunjukkan bahwa aktivitas renang ikan cupang alam menurun dengan penurunan oksigen terlarut di dalam respirometer. Laju ventilasi rata-rata pada perlakuan 5, 10, dan 15 ekor/L diperlihatkan dalam Tabel 2. Hasil pengamatan menunjukkan bahwa laju ventilasi secara berbeda nyata cenderung meningkat dengan kenaikan padat tebar baik pada saat normoksia maupun hipoksia $(p<0,05)$. Namun, jika dibandingkan antara saat normoksia dan hipoksia, laju ventilasi tidak berbeda nyata pada semua perlakuan padat tebar $(p>0,05)$. Sementara itu, untuk konsumsi oksigen dalam sekali bernapas saat hipoksia lebih rendah dan berbeda signifikan dibandingkan saat normoksia pada perlakuan padat tebar 10 dan 15 ekor/L $(p<0,01)$. Konsumsi oksigen dalam sekali bernapas pada perlakuan padat tebar 5 ekor/L tidak menunjukkan nilai yang berbeda nyata antara kondisi normoksia dan hipoksia $(p>0,01)$. Saat normoksia, konsumsi oksigen tertinggi dalam sekali bernapas ditemukan pada perlakuan 5 ekor/L, hal ini berbeda nyata dengan perlakuan 10 dan 15 ekor/L $(p<0,05)$ (Tabel 2).
Berdasarkan hasil pengamatan, kadar oksigen kritis ikan cupang alam memiliki nilai rata-rata $3,31 \pm 0,65 \mathrm{mg} / \mathrm{L}, 3,14 \pm 0,29 \mathrm{mg} / \mathrm{L}$, dan $2,83 \pm 0,19 \mathrm{mg} / \mathrm{L}$ masing-masing untuk padat tebar 5,10 , dan 15 ekor/L. Ketiga perlakuan padat tebar tersebut tidak menunjukkan perbedaan yang nyata antar perlakuan $(p>0,05)$. Sementara itu, dari ketiga perlakuan padat tebar untuk parameter respons stres, kadar glukosa darah tertinggi ratarata ditemukan pada perlakuan padat tebar 15 ekor/L, yaitu 110,3 $\pm 17,9 \mathrm{mg} / \mathrm{dL}$. Nilai tersebut secara berbeda nyata lebih tinggi jika dibandingkan dengan kedua padat tebar yang lain maupun dengan kontrol $(p<0,05)$. Namun, kadar glukosa darah pada perlakuan padat tebar 5, 10 ekor/L, dan kontrol tidak berbeda nyata satu sama lain $(p>0,05)$. Parameter kortisol menunjukkan hasil yang berbeda, yaitu tidak ditemukan perbedaan yang nyata antar perlakuan maupun dengan kontrol $(p>0,05)$. Kadar kortisol rata-rata yang terukur pada penelitian ini berada pada kisaran 2,85 - 5,14 ng/mL (Gambar 1). 
Tabel 2. Laju ventilasi dan konsumsi oksigen per nafas ikan cupang alam (Betta imbellis) pada kepadatan yang berbeda dalam kondisi normoksia dan hipoksia.

Table 2. Ventilation rate and oxygen consumption per breath of crescent betta (Betta imbellis) under different stocking densities during normoxia and hypoxia.

\begin{tabular}{ccccc}
\hline \multirow{2}{*}{$\begin{array}{c}\text { Stocking density } \\
(\text { fish/L) }\end{array}$} & \multicolumn{2}{c}{$\begin{array}{c}\text { Ventilation rate } \\
\text { (time/minute) }\end{array}$} & \multicolumn{2}{c}{$\begin{array}{c}\text { Oxygen consumption } \\
\text { per breath }\left(\mathrm{mg} \mathrm{O}_{2} / \mathrm{g} / \mathrm{breath}\right)\end{array}$} \\
\cline { 2 - 5 } & Normoxia & Hypoxia & Normoxia & Hypoxia \\
\hline 5 & $104.2 \pm 9.2^{\mathrm{a}^{*}}$ & $97.7 \pm 10.3^{\mathrm{a}^{*}}$ & $0.029 \pm 0.003^{\mathrm{y}^{*}}$ & $0.029 \pm 0.019^{\mathrm{k}^{*}}$ \\
10 & $117.7 \pm 8.9^{\mathrm{ab}}$ & $117.6 \pm 5.7^{\mathrm{ab}^{*}}$ & $0.009 \pm 0.002^{\mathrm{x}^{* *}}$ & $0.003 \pm 0.001^{1^{*}}$ \\
15 & $131.0 \pm 8.8^{\mathrm{b}^{*}}$ & $134.0 \pm 12.4^{\mathrm{b}^{*}}$ & $0.007 \pm 0.001^{\mathrm{x}^{* *}}$ & $0.004 \pm 0.001^{1^{*}}$ \\
\hline
\end{tabular}

Keterangan: Nilai merupakan rata-rata \pm SD $(n=3)$. Superskrip alfabet yang berbeda menunjukkan nilai berbeda nyata antara padat tebar yang berbeda ( $p<0,05$, ANOVA satu arah). Superskrip bintang menunjukkan nilai berbeda nyata antara kondisi normoksia dan hipoksia $(p<0,01$, uji-t).

Description: Mean values \pm SD $(n=3)$. Different alphabet superscripts show significant differences between different stocking densities ( $p<0.05$, one-way ANOVA). Asterisk superscripts show significant differences between normoxia and hypoxia ( $p<0.01$, t-test).
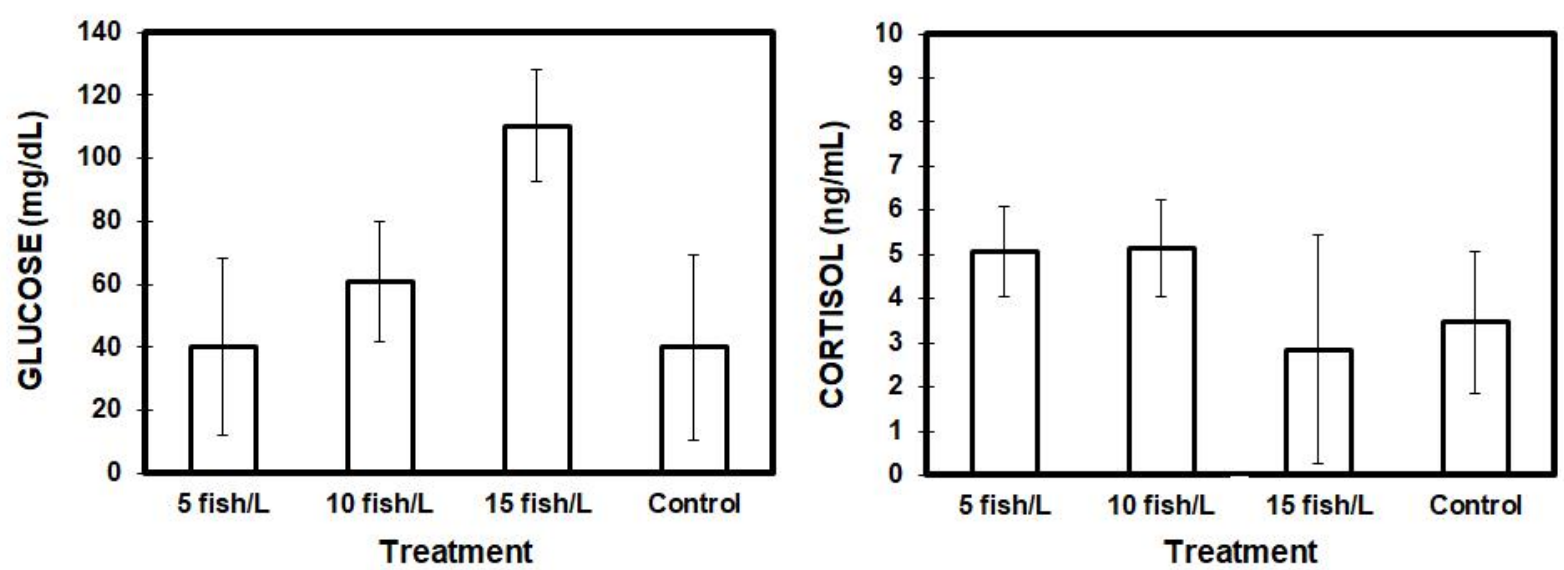

Gambar 1. Kadar glukosa darah dan kortisol ikan cupang alam (Betta imbellis) pada perlakuan padat tebar yang berbeda dan kontrol.

Figure 1. Blood glucose and plasma cortisol level of crescent betta (Betta imbellis) under different stocking density and control treatments.

\section{Pembahasan}

Peningkatan padat tebar ikan cupang alam pada penelitian ini berpengaruh terhadap penurunan tingkat konsumsi oksigen, baik pada kondisi normoksia maupun hipoksia. Pola yang sama juga ditemukan pada penelitian sebelumnya, yaitu pada ikan arctic charr (Salvelinus alpinus) (Jorgensen et al., 1993) dan ikan uceng (Nemacheilus fasciatus) (Iswantari et al., 2019). Sementara itu, pola yang berbeda ditemukan pada beberapa penelitian lain, yaitu pada ikan nila merah (Oreochromis sp.) (Suresh \&Lin, 1992), ikan sole senegal (Solea senegalensis) (SalasLeiton et al., 2008), dan ikan sturgeon atlantik (Acipenser oxyrinchus) (Szczepkowski et al.,
2011). Pada jenis ikan tersebut, tidak ditemukan pengaruh yang signifikan dari peningkatan padat tebar terhadap konsumsi oksigen. Namun, pola yang berlawanan dengan hasil penelitian ini ditemukan dalam penelitian Ruer et al. (1987) yang menunjukkan bahwa peningkatan padat tebar cenderung meningkatkan konsumsi oksigen pada ikan white sturgeon (Acipenser transmontanus). Pola konsumsi oksigen yang bervariasi pada beberapa spesies yang berbeda terhadap perbedaan padat tebar disebabkan perbedaan spesies dalam merespons persaingan individu terkait dengan peningkatan padat tebar. Mishrigi \& Kubo (1978) menyatakan bahwa aktivitas ikan dan konsumsi oksigen dapat berubah dengan keberadaan persaingan individu. 
Hal ini akan berhubungan dengan metabolisme yang dipengaruhi oleh padat tebar seperti pada penelitian Laursen et al. (2013) dan Garcia-Trejo et al. (2016).

Pada perlakuan padat tebar 10 dan 15 ekor/L, konsumsi oksigen dalam kondisi normoksia lebih tinggi dan berbeda signifikan dibandingkan kondisi hipoksia. Menurut Pichavant et al. (2001), hipoksia merupakan salah satu faktor pembatas dalam pertumbuhan ikan. Saat hipoksia, terjadi penurunan aktivitas ataupun komponen-komponen lain yang berkaitan dengan energi dalam individu untuk menyesuaikan diri terhadap penurunan oksigen terlarut dalam air. Hal tersebut dilakukan melalui penurunan proses metabolisme dalam tubuh secara terkontrol (Jobling, 1993; Petersen \& Gamperl, 2010; Richards, 2011). Selain pada penelitian ini, fenomena ini juga terjadi pada ikan lain dari penelitian terdahulu, yaitu pada ikan white sturgeon (Acipenser transmontanus) (Burggren and Randall, 1978),ikan gabus (Channa striata) (Lefevre et al., 2012), ikan rainbow trout (Oncorhynchus mykiss) (Magnoni et al., 2018; Svendsen et al., 2012), ikan nila (Oreochromis niloticus) (Prakoso \& Chang, 2018, dan ikan uceng (Nemacheilus fasciatus) (Iswantari et al., 2019).

Untuk parameter laju ventilasi, ikan cupang alam tidak menunjukkan perbedaan nilai yang nyata antara kondisi normoksia dan hipoksia. Namun, secara keseluruhan terdapat tendensi peningkatan laju ventilasi seiring dengan peningkatan padat tebar. Penelitian Rees et al. (2009) terhadap ikan gulf killi (Fundulus grandis) dan penelitian Tzaneva et al. (2011) terhadap ikan mas koki (Carassius auratus) menunjukkan bahwa saat hipoksia laju ventilasi ikan tersebut lebih tinggi dibandingkan saat normoksia. Pola yang berlawanan terjadi pada penelitian Lefevre et al. (2011) terhadap ikan patin (Pangasianodon hypophthalmus) yang menunjukkan laju ventilasi saat hipoksia yang lebih rendah dibandingkan normoksia. Perbedaan pola laju ventilasi pada beberapa spesies ikan tersebut merupakan strategi dari masing-masing spesies untuk menyesuaikan diri saat hipoksia, baik dengan cara meningkatkan maupun menurunkan frekuensi pernapasan (Perry et al., 2009).

Pada penelitian ini, konsumsi oksigen dalam sekali napas pada ikan cupang alam menunjukkan nilai yang berbeda nyata pada perlakuan padat tebar 5 ekor/L dibandingkan dengan padat tebar 10 dan 15 ekor/L, pada saat normoksia maupun hipoksia. Nilai tersebut dapat berarti bahwa padat tebar yang lebih rendah menghasilkan metabolisme yang lebih baik pada ikan cupang alam. Hal tersebut mungkin akan berdampak pada pertumbuhan yang cenderung lebih baik pada pemeliharaan dengan padat tebar rendah. Hubungan antara padat tebar dan pertumbuhan tersebut telah banyak diteliti pada beberapa spesies ikan air tawar, di antaranya ikan botia (Chromobotia macracanthus) (Priyadi et al., 2010), ikan gurami (Osphronemus goramy) (Arifin et al., 2019a), ikan uceng (Nemacheilus fasciatus) (Subagja et al., 2019), ikan tambakan (Helostoma temminckii) (Arifin et al., 2019b), ikan lalawak (Barbonymus balleroides) (Arifin et al., 2017b), ikan betutu (Oxyeleotris marmorata) (Prihadi et al., 2017), ikan semah (Tor douronensis) (Subagja \& Radona, 2017), ikan corydoras (Corydoras aeneus) (Diatin et al., 2015), dan ikan tawes (Barbodes gonionotus) (Faizul \& Christianus, 2013). Berdasarkan beberapa penelitian tersebut, masing-masing spesies memiliki respons yang berbeda terhadap peningkatan padat tebar. Jika parameter konsumsi oksigen per nafas dalam penelitian ini dihubungkan dengan parameter laju ventilasi dan konsumsi oksigen, terlihat bahwa ikan cupang alam merespon peningkatan padat tebar dengan peningkatan laju ventilasi dan penurunan konsumsi oksigen. Menurut Dalla Valle et al. (2003), aktivitas operkulum dapat digunakan untuk mengestimasi metabolisme aerobik ikan dalam kondisi lingkungan alaminya. Pada penelitian ini, peningkatan laju ventilasi yang diamati dari gerakan operkulum diduga akibat aktivitas saat terjadi persaingan antar individu sejalan dengan padat tebar yang semakin meningkat. Namun, hal tersebut tidak berkorelasi secara positif karena pada saat yang bersamaan ikan cupang alam merespon peningkatan padat tebar dengan melakukan efisiensi metabolisme, sehingga terjadi penurunan konsumsi oksigen. Hal tersebut didukung oleh data nilai konsumsi oksigen per napas yang mengalami penurunan seiring dengan peningkatan padat tebar. Sementara itu, jika dihubungkan dengan respon stres ikan yaitu berupa data kadar kortisol dan glukosa dalam darah yang diamati pada penelitian ini, khususnya pada parameter glukosa darah, maka terlihat bahwa peningkatan padat tebar menyebabkan peningkatan kadar glukosa darah yang signifikan. Hal tersebut dapat diartikan bahwa terjadi stres akibat peningkatan padat tebar, sehingga berpotensi memberikan dampak negatif terhadap metabolisme dan pertumbuhan ikan cupang alam. Peningkatan kortisol dan glukosa darah yang merupakan indikator stres akan menyebabkan ikan harus merespon kondisi tersebut dengan mengalokasikan sebagian energi 
yang ada di dalam tubuh untuk mengatasi stres tersebut, sehingga energi yang seharusnya dibutuhkan untuk proses metabolisme menjadi berkurang (Barton \& Schreck, 1987). Hal tersebut menyebabkan konsumsi oksigen ikan cupang alam dalam penelitian ini mengalami penurunan saat kondisi stres. Pengaruh negatif dari peningkatan padat tebar terhadap tingkat stres ikan juga ditemukan pada beberapa penelitian terdahulu, seperti pada ikan nila (Oreochromis niloticus) (Barcellos et al., 1999), ikan mas (Cyprinus carpio) (Ruane et al., 2002), dan ikan baung (Hemibagrus nemurus) (Prakoso et al., 2019a). Hasil penelitian pada ikan cupang alam ini berkaitan dengan pernyataan dari Barcellos et al. (2004) dan Laiz-Carrion et al. (2012) yang mengemukakan bahwa dampak negatif dari peningkatan padat tebar berhubungan dengan kontak antar individu, persaingan dalam memperoleh makanan, dan stres akibat peningkatan padat tebar yang berdampak negatif terhadap metabolisme dan pertumbuhan ikan. Namun, jika dilihat dari parameter stres lainnya pada penelitian ini, yaitu kortisol, tidak ditemukan adanya perbedaan yang nyata kadar kortisol dengan adanya peningkatan padat tebar. Tidak adanya respons yang signifikan pada parameter kortisol terhadap peningkatan padat tebar ini serupa dengan penelitian sebelumnya pada ikan rainbow trout (Salmo gairdneri) (Laidley \&Leatherland, 1988) dan benih ikan lele (Clarias gariepinus) (van de Nieuwegiessen et al., 2008). Hal tersebut kemungkinan disebabkan oleh respons kortisol yang terganggu sebagian terkait dengan penurunan regulasi reseptor ACTH atau kortisol karena stres kronis (Wendelaar Bonga, 1997). Gangguan respon kortisol tersebut juga berpengaruh terhadap peningkatan pembersihan kortisol dalam tubuh ikan (Wendelaar Bonga, 1997).

Kadar oksigen kritis merupakan kadar oksigen saat ikan tidak mampu lagi mempertahankan pasokan oksigen yang memadai untuk kecukupan metabolisme tubuhnya (Jobling, 1994). Berdasarkan data pengukuran tingkat konsumsi oksigen pada kondisi hipoksia, kadar oksigen kritis $\left(\mathrm{O}_{2 \text { crit }}\right)$ pada ikan cupang alam dapat diprediksi. Hasil pengamatan menunjukkan bahwa kadar oksigen kritis ikan cupang alam tidak berbeda nyata antar perlakuan padat tebar (P>0,05). Randall (1982) menyatakan bahwa kadar oksigen kritis bagi ikan berbeda-beda, tergantung spesies dan tingkat adaptasinya. Jika dibandingkan dengan penelitian terdahulu, variasi tinggi rendah nilai kadar oksigen kritis dipengaruhi oleh faktor suhu (Ott et al., 1980; Rombough, 1988, Mamun et al., 2013) dan stres akibat kondisi hipoksia (Borger et al., 1998; Herbert \& Steffensen, 2005; Arifin et al., 2017b; Prakoso \& Chang, 2018; Iswantari et al., 2019). Kadar oksigen kritis ini dapat digunakan sebagai pendekatan dalam memprediksi nilai toleransi batas bawah oksigen terlarut pada ikan yang berpengaruh negatif terhadap pertumbuhan dan reproduksi (Cruz-Neto \& Steffensen, 1997). Berdasarkan informasi tersebut, perbedaan padat tebar tidak memiliki pengaruh yang nyata terhadap kadar oksigen kritis pada ikan cupang alam.

Pada kondisi padat tebar 5 ekor/L, kondisi hipoksia tidak membuat ikan menjadi stres karena konsumsi oksigen pada kondisi hipoksia tidak berbeda nyata dari kondisi normoksia (Tabel 1), Namun, pada padat tebar 10 ekor/L atau lebih, kondisi hipoksia akan membuat ikan menjadi stres. Hal ini juga diperkuat dengan data kadar glukosa darah pada penelitian ini yang meningkat dengan semakin tingginya padat tebar, sehingga kondisi padat tebar ideal untuk pemeliharaan ikan cupang alam dengan ukuran panjang 2-3 cm berdasarkan penelitian ini adalah 5 ekor/L. Selain itu, laju ventilasi ikan cupang alam juga meningkat dengan semakin tingginya padat tebar. Perry et al. (2009) menyatakan bahwa laju ventilasi pada masing-masing spesies ikan bervariasi tergantung strategi spesies tersebut untuk beradaptasi. Namun sebaliknya, konsumsi oksigennya mengalami penurunan dengan peningkatan padat tebar. Penurunan konsumsi oksigen akibat padat tebar ini serupa dengan penelitian terdahulu pada ikan rainbow trout (Oncorhynchus mykiss) (Itazawa et al., 1978) dan ikan ayu sweetfish (Plecoglossus altivelis) (Umezawa et al., 1983). Hal ini berhubungan dengan respon ikan terhadap peningkatan padat tebar. Persaingan antarindividu yang lebih tinggi pada padat tebar yang lebih tinggi akan menyebabkan ikan mengalihkan sebagian energi yang seharusnya digunakan dalam metabolisme untuk beradaptasi terhadap stres akibat padat tebar yang tinggi. Ini umumnya dikaitkan dengan penurunan aktivitas ikan pada kondisi padat tebar yang lebih tinggi atau dikenal dengan istilah calming effect (Ruer et al., 1987). Pada penelitian ini, ikan cupang alam merespon peningkatan padat tebar dengan penurunan aktivitas dan peningkatan laju ventilasi. Akan tetapi, meskipun terjadi peningkatan laju ventilasi, terjadi penurunan konsumsi oksigen dalam sekali bernapas pada padat tebar yang lebih tinggi akibat adanya penurunan aktivitas ikan,sehingga dihasilkan konsumsi oksigen yang lebih rendah pada padat tebar yang lebih tinggi. 


\section{Kesimpulan}

Peningkatan padat tebar mengakibatkan penurunan konsumsi oksigen dan peningkatan stres pada ikan cupang alam. Konsumsi oksigen tertinggi ditemukan pada perlakuan padat tebar 5 ekor/L yang berbeda nyata dari perlakuan 10 dan 15 ekor/L. Ikan cupang alam merespon peningkatan padat tebar dengan penurunan aktivitas dan peningkatan laju ventilasi. Meningkatnya laju ventilasi memiliki korelasi negatif dengan konsumsi oksigen dalam sekali bernapas pada kondisi padat tebar yang lebih tinggi, sehingga berakibat pada penurunan aktivitas ikan. Hal tersebut yang menyebabkan pada kondisi padat tebar yang lebih tinggi terjadi penurunan konsumsi oksigen. Berdasarkan observasi kadar oksigen kritis, untuk menghindari stres dan kematian, maka disarankan kondisi oksigen terlarut dalam sistem pemeliharaan ikan ini dipertahankan agar tidak mendekati atau di bawah 2,5 mg/L. Hasil pengukuran konsumsi oksigen dan parameter respons stres menunjukkan bahwa padat tebar 5 ekor/L merupakan padat tebar yang ideal bagi ikan cupang alam ukuran 2-3 $\mathrm{cm}$.

\section{Persantunan}

Penulis mengucapkan terima kasih kepada Bapak Anang Hari Kristanto, Budi Setiawan, dan Sutarman atas kontribusinya selama penelitian berlangsung. Penelitian ini dibiayai oleh DIPA APBN Balai Riset Budidaya Ikan Hias Tahun 2019.

\section{Daftar Pustaka}

Arifin, O. Z.,Prakoso, V. A., \& Pantjara, B.(2017a). Ketahanan ikan tambakan (Helostoma temminckii) terhadap beberapa parameter kualitas air dalam lingkungan budidaya. Jurnal Riset Akuakultur,12(3), 241-251.

Arifin, O. Z., Subagja, J., Prakoso, V. A., \& Suhud, E. H. (2017b). Effect of stocking density on growth performance of domesticated barb (Barbonymus balleroides). Indonesian Aquaculture Journal,12(1), 1-6.

Arifin, O. Z., Prakoso, V. A., Kristanto, A. H., Pouil, S., \& Slembrouck, J. (2019a). Effect of stocking density on growth, food intake and survival of giant gourami (Osphronemus goramy, Lacepède) larvae. Aquaculture, 509, 159-166.
Arifin, O. Z., Cahyanti, W., \& Prakoso, V. A. (2019b). Keragaan pertumbuhan ikan tambakan (Helostoma temminckii Cuvier, 1829) dengan kepadatan berbeda. Media Akuakultur, 14(2), 83-87.

Barcellos, L. G., Nicolaiewsky, S., De Souza, S. G., \& Lulhier, F. (1999). The effects of stocking density and social interaction on acute stress response in Nile tilapia Oreochromis niloticus (L.) fingerlings. Aquaculture Research, 30(11 12), 887-892.

Barcellos, L. J. G., Kreutz, L. C., Quevedo, R. M., Fioreze, I., Cericato, L., Soso, A. B., ... \& Ritter, F. (2004). Nursery rearing of jundiá, Rhamdia quelen (Quoy \& Gaimard) in cages: cage type, stocking density and stress response to confinement. Aquaculture, 232(1-4), 383-394.

Barton, B. A., \& Schreck, C. B. (1987). Metabolic cost of acute physical stress in juvenile steelhead. Transactions of the American Fisheries Society, 116(2), 257-263.

Borger, R., de Boeck, G.,van Auderke, J., Dommisse, R., Blust, R., \&van den Linden, A. (1998). Recovery of the energy metabolism after a hypoxic challenge at different temperature conditions: a ${ }^{31} \mathrm{P}$ nuclear magnetic resonance spectroscopy study with common carp. Comparative Biochemistry and Physiology Part A: Molecular \& Integrative Physiology, 120(1), 143-150.

Boyd, C. E. (1982). Water quality management for pond fish culture. Elsevier Scientific Publishing Co.

Brett, J. R. (1964). The respiratory metabolism and swimming performance of young sockeye salmon. Journal of the Fisheries Board of Canada, 21(5), 1183-1226.

Burggren, W. W., \& Randall, D. J. (1978). Oxygen uptake and transport during hypoxic exposure in the sturgeon Acipenser transmontanus. Respiration Physiology, 34(2), 171-183.

Chang, Y. J., Jeong, M. H., Min, B. H., Neill, W. H., \& Fontaine, L. P. (2005). Effects of photoperiod, temperature, and fish size on oxygen consumption in the black porgy Acanthopagrus schlegeli. Fisheries and Aquatic Sciences, 8(3), 142-150.

Cindelaras, S., Prasetio, A. B., \& Kusrini, E. (2015). Embryonic and early larvae development of wild betta (Betta imbellis Ladiges 1975). Widyariset, 1(1), 1-10.

Cook, D. G., \& Herbert, N. A. (2012). The physiological and behavioural response of 
juvenile kingfish (Seriola lalandi) differs between escapable and inescapable progressive hypoxia. Journal of Experimental Marine Biology and Ecology, 413, 138-144.

Cruz-Neto, A.P., \& Steffensen, J. F. (1997). The effects of acute hypoxia and hypercapnia on oxygen consumption of the freshwater European eel. Journal of Fish Biology, 50,759-769.

Dalla Valle, A. Z., Rivas Diaz, R., \& Claireaux, G. (2003). Opercular differential pressure as a predictor of metabolic oxygen demand in the starry flounder. Journal of Fish Biology, 63(6), 1578-1588.

De las Heras, V., Martos-Sitcha, J. A., Yúfera, M., Mancera, J. M., \& Martínez-Rodríguez, G. (2015). Influence of stocking density on growth, metabolism and stress of thicklipped grey mullet (Chelon labrosus) juveniles. Aquaculture, 448, 29-37.

Diatin, I., Suprayudi, M. A., Budiardi, T., \& Surawidjaja, E. H. (2015). Intensive culture of corydoras ornamental fish (Corydoras aeneus): evaluation of stocking density and water exchange. AACL Bioflux, 8(6), 975987.

Domenici, P., Herbert, N. A., Lefrançois, C., Steffensen, J. F., \& McKenzie, D. J. (2013). The effect of hypoxia on fish swimming performance and behaviour. In Swimming Physiology of Fish (pp. 129-159). Berlin, Heidelberg: Springer.

Faizul, M. I. M., \& Christianus, A. (2013). Salinity and stocking density effect on growth and survival of Barbodes gonionotus (Bleeker, 1850) fry. Journal of Fisheries and Aquatic Science, 8(2), 419424.

Faturrohman, K. (2017). Penentuan kadar oksigen terlarut optimum untuk pertumbuhan benih kepiting bakau Scylla serrata dalam sistem resirkulasi. [Tesis]. Bogor (ID): Institut Pertanian Bogor.

García-Trejo, J. F., Peña-Herrejon, G. A., SotoZarazúa, G. M., Mercado-Luna, A., Alatorre-Jácome, O., \& Rico-García, E. (2016). Effect of stocking density on growth performance and oxygen consumption of Nile tilapia (Oreochromis niloticus) under greenhouse conditions. Latin American Journal of Aquatic Research, 44(1), 177-183.

Hayuningtyas, E. P., \& Kusrini, E. (2016). Performa pertumbuhan ikan cupang alam (Betta imbellis) yang diberi hormon pertumbuhan rekombinan melalui perendaman dan pakan alami. Media Akuakultur, 11(2), 87-95.

Hepher, B., \& Pruginin, Y. (1981). Commercial fish farming with special reference to fish culture in Israel. John Wiley and Sons, New York.

Herbert, N. A.,\& Steffensen, J. F. (2005). The response of Atlantic cod, Gadus morhua, to progressive hypoxia: fish swimming speed and physiological stress. Marine Biology, 147(6), 1403-1412.

Hui, T. H., \& Ng, P. K. (2005). The labyrinth fishes (Teleostei: Anabantoidei, Channoidei) of Sumatra, Indonesia. The Raffles Bulletin of Zoology, 13, 115-138.

Iswantari, A., Kurniawan, K., Priadi, B., Prakoso, V. A., \& Kristanto, A. H. (2019). Konsumsi oksigen ikan uceng Nemacheilus fasciatus (Valenciennes, 1846) pada kondisi padat tebar yang berbeda. Oseanologi dan Limnologi di Indonesia, 4(2), 79-87.

Itazawa, Y., Matsumoto, T., \& Kanda, T. (1978). Group effects on physiological and ecological phenomena in fish, 1: Group effect on the oxygen consumption of the rainbow trout and the medaka. Bulletin of the Japanese Society of Scientific Fisheries, 44(9), 965-969 (in Japanese).

Jeong, M. H., Kim, Y. S., Min, B. H., \& Chang, Y. J. (2007). Effect of fish number in respiratory chamber on routine oxygen consumption of black porgy Acanthopagrus schlegeli reared in seawater or freshwater. Journal of Aquaculture, 20(2), 121-126.

Jobling, M. (1993). Bioenergetics: feed intake and energy partitioning. In J. C. Rankin \& F. B. Jensen (Eds.),Fish Ecophysiology, Fish and Fisheries Series 9 (pp. 16-28). London, England: Chapman \& Hall.

Jobling, M. (1994). Fish Bioenergetics. London, England: Chapman \& Hall.

Jorgensen, E. H., Christiansen, J. S., \& Jobling, M. (1993). Effects of stocking density on food intake, growth performance and oxygen consumption in Arctic charr (Salvelinus alpinus). Aquaculture, 110(2), 191-204.

Kadarini, T., Sholichah, L., \& Gladiyakto, M. (2010). Pengaruh padat penebaran terhadap sintasan dan pertumbuhan benih ikan hias silver dolar (Metynnis hypsauchen) dalam sistem resirkulasi. Prosiding Forum Inovasi Teknologi Akuakultur 2010 (pp. 409-416). Jakarta: Pusat Penelitian dan Pengembangan Perikanan Budidaya. 
Kawamoto, N. (1977). Fish Physiology.Tokyo, Japan: Koseisha-Koseikaku (in Japanese).

Koolhaas, J. M., Korte, S. M., De Boer, S. F., Van Der Vegt, B. J., Van Reenen, C. G., Hopster, H., De Jong, I. C., Ruis, M. A. W.,\& Blokhuis, H. J. (1999). Coping styles in animals: current status in behavior and stress-physiology. Neuroscience

Biobehavioral Reviews, 23(7), 925-935.

Kulkarni, A. C., Kuppusamy, P., \& Parinandi, N. (2007). Oxygen, the lead actor in the pathophysiologic drama: enactment of the trinity of normoxia, hypoxia, and hyperoxia in disease and therapy. Antioxidants \& Redox Signaling, 9(10), 1717-1730.

Kusrini, E., Alimuddin, Zairin, M., \& Sulistyowati, D. T. (2016). Gene transfer on Betta imbellis through transfection method with different DNA concentration. Indonesian Aquaculture Journal, 11(1), 17.

Kusrini, E., Alimuddin, Zairin, M., \& Sulistyowati, D. T. (2018). Foreign growth hormone gene transmission and expression in F1 transgenic betta fish (Betta imbellis). Pakistan Journal of Biotechnology, 15(1), 1-9.

Laidley, C. W., \& Leatherland, J. F. (1988). Cohort sampling, anaesthesia and stocking density effects on plasma cortisol, thyroid hormone, metabolite and ion levels in rainbow trout, Salmo gairdneri Richardson. Journal of Fish Biology, 33(1), 73-88.

Laiz-Carrión, R., Viana, I. R., Cejas, J. R., RuizJarabo, I., Jerez, S., Martos, J. A., ... \& Mancera, J. M. (2012). Influence of food deprivation and high stocking density on energetic metabolism and stress response in red porgy, Pagrus pagrus L. Aquaculture International, 20(3), 585-599.

Laursen, D. C., Silva, P. I., Larsen, B. K., \& Höglund, E. (2013). High oxygen consumption rates and scale loss indicate elevated aggressive behaviour at low rearing density, while elevated brain serotonergic activity suggests chronic stress at high rearing densities in farmed rainbow trout. Physiology \& Behavior, 122, 147154.

Lays, N., Iversen, M. M. T., Frantzen, M., \& Jørgensen, E. H. (2009). Physiological stress responses in spotted wolffish (Anarhichas minor) subjected to acute disturbance and progressive hypoxia. Aquaculture, 295(1-2), 126-133.
Lefevre, S., Wang, T., Phuong, N. T., \& Bayley, M. (2011). Hypoxia tolerance and partitioning of bimodal respiration in the striped catfish (Pangasianodon hypophthalmus). Comparative Biochemistry and Physiology Part A: Molecular \& Integrative Physiology, 158(2), 207-214.

Lefevre, S., Phuong, N. T., Wang, T., \& Bayley, M. (2012). Effects of hypoxia on the partitioning of oxygen uptake and the rise in metabolism during digestion in the airbreathing fish Channa striata. Aquaculture, 364, 137-142.

Magnoni, L. J., Eding, E., Leguen, I., Prunet, P., Geurden, I., Ozório, R. O., \& Schrama, J. W. (2018). Hypoxia, but not an electrolyteimbalanced diet, reduces feed intake, growth and oxygen consumption in rainbow trout (Oncorhynchus mykiss). Scientific Reports, 8(1), 4965.

Mamun, S. M., Focken, U., \& Becker. K. (2013). A respirometer system to measure critical and recovery oxygen tensions of fish under simulated diurnal fluctuations in dissolved oxygen. Aquaculture International, 21, 3144.

Millán-Cubillo, A. F., Martos-Sitcha, J. A., RuizJarabo, I., Cárdenas, S., \& Mancera, J. M. (2016). Low stocking density negatively affects growth, metabolism and stress pathways in juvenile specimens of meagre (Argyrosomus regius, Asso 1801). Aquaculture, 451, 87-92.

Mishrigi, S., \& Kubo, T. (1978). Effects of territoriality on oxygen consumption in Tilapia nilotica. Bulletin of the Faculty of Fisheries Hokkaido University, 29(4), 308312.

Morgan, J. D., \& Iwama, G. K. (2011). Measurements of stressed states in the field. In G. K. Iwama, A. D. Pickering, J. P. Sumpter \& C. B. Schreck (Eds.), Fish Stress and Health in Aquaculture(pp. 247270). Cambridge: Cambridge University Press.

Murniasih, S., Cindelaras, S., Rahmawati, R., \& Kusrini, E. (2012). Pemijahan dan pemeliharaan larva ikan wild betta (Betta imbellis). In Haryanti, Rachmansyah, K.Sugama, A. Parenrengi, A. Sudradjat, Imron, A. Sunarto, G. S. Sumiarsa, Z. I. Azwar \& A. H. Kristanto (Eds.), Prosiding Forum Inovasi Teknologi Akuakultur 2012 (pp. 343-349). Jakarta: Pusat Penelitian dan Pengembangan Perikanan Budidaya. 
Ni, M., Wen, H., Li, J., Chi, M., Bu, Y., Ren, Y., Zhang, M., Song, Z., \& Ding, H. (2014). The physiological performance and immune responses of juvenile Amur sturgeon (Acipenser schrenckii) to stocking density and hypoxia stress. Fish \& Shellfish Immunology, 36(2), 325-335.

Ott, M. E., Heisler, N.,\& Ultsch, G. R. (1980). A re-evaluation of the relationship between temperature and the critical oxygen tension in freshwater fishes. Comparative Biochemistry and Physiology Part A: Physiology, 67(3), 337-340.

Overli, O., Sørensen, C., Pulman, K. G., Pottinger, T. G., Korzan, W., Summers, C. H., \& Nilsson, G. E. (2007). Evolutionary background for stress-coping styles: relationships between physiological, behavioral, and cognitive traits in nonmammalian vertebrates. Neuroscience \& Biobehavioral Reviews, 31(3), 396-412.

Perry, S. F., Jonz, M. G., \& Gilmour, K. M. (2009). Chapter 5. Oxygen sensing and the hypoxic ventilatory response. In J. G. Richards, A. P. Farrell, \& C. J. Brauner (Eds.), Fish Physiology. Vol. 27: Hypoxia (pp. 193-253). New York, United States: Academic Press.

Petersen, L. H., \& Gamperl, A. K. (2010). Effect of acute and chronic hypoxia on the swimming performance, metabolic capacity and cardiac function of Atlantic cod (Gadus morhua). Journal of Experimental Biology, 213(5), 808-819.

Pichavant, K., Person-Le-Ruyet, J., Le Bayon, N., Severe, A., Le Roux A., Quemener, L., Maxime, V., Nonnotte, G., \& Boeuf, G. (2000). Effects of hypoxia on growth and metabolism of juvenile turbot. Aquaculture, 188(1-2), 103-114.

Pichavant, K., Person Le Ruyet, J., Bayon, N. L., Severe, A., Roux, A. L., \& Boeuf, G. (2001). Comparative effects of long term hypoxia on growth, feeding and oxygen consumption in juvenile turbot and European sea bass. Journal of Fish Biology, 59(4), 875-883.

Pörtner, H. O., Heisler, N., \& Grieshaber, M. K. (1985). Oxygen consumption and mode of energy production in the intertidal worm Sipunculus nudus L.: definition and characterization of the critical PO2 for an oxyconformer. Respiration

Physiology, 59(3), 361-377.

Prakoso, V. A., Kim, K. T., Min, B. H., Gustiano, R., \& Chang, Y. J. (2016). Lethal dissolved oxygen and blood properties of grey mullets
Mugil Cephalus in seawater and freshwater. Berita Biologi, 15(1), 89-94.

Prakoso, V. A.,\& Chang, Y. J. (2018). Effects of hypoxia on oxygen consumption of tilapia fingerlings

(Oreochromis niloticus). Oseanologi dan Limnologi di Indonesia, 3(2), 165-171.

Prakoso V. A, Sinansari, S., \& Kristanto, A. H. (2019a). Oxygen consumption and blood glucose level of Asian redtail catfish (Hemibagrus nemurus) fingerlings exposed to hypoxia. In Aunurohim, W. Muslihatin, I. Desmawati, N. N. Sa'adah, M. A. P. Utomo, N. H. Alami, F. K. Muzaki, N. M. Ashuri \& T. B. Saputro (Eds.), The Proceeding of $4^{\text {th }}$ International Biology Conference - 2018: Exploring gene to ecosystem for human welfare (pp. 54-59). Surabaya: Biology Department, Faculty of Science, Institut Teknologi Sepuluh Nopember.

Prakoso, V. A., Pouil, S., Prabowo, M. N. I., Sundari, S., Arifin, O. Z., Subagja, J., Affandi, R., Kristanto, A. H., \& Slembrouck, J. (2019b). Effects of temperature on the zootechnical performances and physiology of giant gourami (Osphronemus goramy) larvae. Aquaculture, 510, 160-168.

Prasetio, A. B., Kusrini, E., Kusumah, R. V., Cindelaras, S., \& Murniasih, S. (2013). Efektivitas metode transfeksi dalam transfer gen pada zigot ikan cupang alam (wild betta), Betta imbellis. Jurnal Riset Akuakultur, 8(2), 191-199.

Prihadi, T. H., Saputra, A., Huwoyon, G. H., \& Pantjara, B. (2018). Pengaruh kepadatan terhadap sintasan, pertumbuhan, dan gambaran darah benih ikan betutu Oxyeleotris marmorata. Jurnal Riset Akuakultur, 12(4), 341-350.

Priyadi, A., Ginanjar, R., Permana, A., \& Slembrouck, J. (2010). Tingkat densitas larva botia (Chromobotia macracanthus) dalam satuan volume air pada akuarium resirkulasi. Prosiding Forum Inovasi Teknologi Akuakultur 2010 (pp. 439-446). Jakarta: Pusat Penelitian dan Pengembangan Perikanan Budidaya.

Rahmawati, R., \& Kusrini, E. (2016). Optimasi suhu pemeliharaan terhadap pertumbuhan larva ikan cupang, Betta imbellis. In K. Sugama, Wijopriono, I. N. A. Giri, Rachmansyah, Haryanti, Alimuddin, I. N. Radiarta, S. Juwana \& D. E. D. Setiono (Eds.), Prosiding Forum Inovasi Teknologi Akuakultur 2016 (pp. 385-391). Jakarta: 
Pusat Penelitian dan Pengembangan Perikanan Budidaya.

Randall, D. (1982). The control of respiration and circulation in fish during exercise and hypoxia. Journal of Experimental Biology, 100(1),275-288.

Rees, B. B., Boily, P., \& Williamson, L. A. C. (2009). Exercise- and hypoxia-induced anaerobic metabolism and recovery: a student laboratory exercise using teleost fish. Advances in Physiology Education, 33(1), 72-77.

Ren, Y., Wen, H., Li, Y., Li, J., He, F., \& Ni, M. (2017). Effects of stocking density on lipid deposition and expression of lipid-related genes in Amur sturgeon (Acipenser schrenckii). Fish Physiology and Biochemistry, 43(6), 1707-1720.

Richards, J. G. (2011). Physiological, behavioral and biochemical adaptations of intertidal fishes to hypoxia. Journal of Experimental Biology, 214(2),191-199.

Rombough, P. J. (1988). Growth, aerobic metabolism, and dissolved oxygen requirements of embryos and alevins of steelhead, Salmo gairdneri. Canadian Journal of Zoology, 66(3), 651-660.

Ruane, N. M., Carballo, E. C., \& Komen, J. (2002). Increased stocking density influences the acute physiological stress response of common carp Cyprinus carpio (L.). Aquaculture Research,33(10), 777784.

Ruer, P. M., Cech Jr, J. J., \& Doroshov, S. I. (1987). Routine metabolism of the white sturgeon, Acipenser transmontanus: effect of population density and hypoxia. Aquaculture, 62(1), 45-52.

Sadoul, B., \& Geffroy, B. (2019). Measuring cortisol, the major stress hormone in fishes. Journal of Fish Biology, 94(4), 540555.

Salas-Leiton, E., Anguis, V., Manchado, M., \& Canavate, J. P. (2008). Growth, feeding and oxygen consumption of Senegalese sole (Solea senegalensis) juveniles stocked at different densities. Aquaculture, 285(1-4), 84-89.

Schreck, C. B., \& Tort, L. (2016). The concept of stress in fish. In Fish physiology (Vol. 35, pp. 1-34). Academic Press.

Schurmann, H., \& Steffensen, J. F. (1997). Effects of temperature, hypoxia and activity on the metabolism of juvenile Atlantic cod. Journal of Fish Biology, 50(6), 11661180.
Subagja, J., \& Radona, D. (2017). Produktivitas pascalarva ikan semah Tor douronensis (Valenciennes, 1842) pada lingkungan ex situ dengan padat tebar berbeda. Jurnal Riset Akuakultur, 12(1), 41-48.

Subagja, J., Prakoso, V. A., Arifin, O. Z., \& Kristanto, A. H. (2019). Pengaruh perbedaan padat tebar larva terhadap pertumbuhan dan sintasan pada ikan uceng (Nemacheilus fasciatus). Berita Biologi, 18(2), 209-214.

Suresh, A. V., \& Lin, C. K. (1992). Effect of stocking density on water quality and production of red tilapia in a recirculated water Engineering, 11(1),1-22.

Svendsen, J. C., Steffensen, J. F., Aarestrup, K., Frisk, M., Etzerodt, A., \& Jyde, M. (2012). Excess posthypoxic oxygen consumption in rainbow trout (Oncorhynchus mykiss): recovery in normoxia and hypoxia. Canadian Journal of Zoology, 90(1),1-11.

Szczepkowski, M., Szczepkowska, B., \& Piotrowska, I. (2011). Impact of higher stocking density of juvenile Atlantic sturgeon, Acipenser oxyrinchus Mitchill, on fish growth, oxygen consumption, and ammonia excretion. Archives of Polish Fisheries, 19(2), 59-67.

Tripathi, R. K., Mohindra, V., Singh, A., Kumar, R., Mishra, R. M., \& Jena, J. K. (2013). Physiological responses to acute experimental hypoxia in the air-breathing Indian catfish, Clarias batrachus (Linnaeus, 1758). Journal of Biosciences, 38(2), 373383.

Tzaneva, V., Bailey, S., \& Perry, S. F. (2011). The interactive effects of hypoxemia, hyperoxia, and temperature on the gill morphology of goldfish (Carassius auratus). American Journal of PhysiologyRegulatory, Integrative and Comparative Physiology, 300(6),344-1351.

Umezawa, S. I., Adachi, S., \& Taneda, K. (1983). Group effect on oxygen consumption of the ayu (Plecoglossus altivelis) in relation to growth stage. Japanese Journal of Ichthyology, 30(3), 261-267.

van de Nieuwegiessen, P. G., Boerlage, A. S., Verreth, J. A., \& Schrama, J. W. (2008). Assessing the effects of a chronic stressor, stocking density, on welfare indicators of juvenile African catfish, Clarias gariepinus Burchell. Applied Animal Behaviour Science, 115(3-4), 233-243. 
Sinansari et al.

Wahyu, Supriyono E., Nirmala K., \& Enang H. (2015). Pengaruh kepadatan ikan selama pengangkutan terhadap gambaran darah, $\mathrm{pH}$ darah dan kelangsungan benih ikan gabus Channa striata (Bloch, 1793). Jurnal Ikhtiologi Indonesia, 15(2),165-177.

Wares, W. D., \& Igram, R.(1979). Oxygen consumption in the fathead minnow (Pimephales promelas Rafinesque)-I: Effects of weight, temperature, group size, oxygen level and opercular movement rate as a function of temperature. Comparative Biochemistry and Physiology Part A: Physiology, 62(2), 351-356.
Watkins, D., Cooperstein, S. J., \&Lazarow, A. (2008). Effect of alloxan on permeability of pancreatic islet tissue in vitro. American Journal of Physiology,207(2), 436-440.

Wedemeyer, G. A., Barton, B. B., \& McLeay, D. J. (1990). Stress and acclimation. In C. B. Schreck, \& P.B. Moyle (Eds.),Methods for Fish Biology(pp. 451-489). Bethesda, MD: American Fisheries Society.

Wendelaar Bonga, S. E. (1997). The stress response in fish. Physiological reviews, 77(3), 591-625. 